\title{
"DYNAMICS OF MIKIR HILLS PLATEAU AND ITS VICINITY: INFERENCES ON KOPILI AND BOMDILA FAULTS IN NORTHEASTERN INDIA THROUGH SEISMOTECTONICS, GRAVITY AND MAGNETIC ANOMALIES,
}

\author{
Sangeeta Sharma ${ }^{1}$, Jogendra Nath Sarma ${ }^{1}$ and Saurabh Baruah ${ }^{1, *}$ \\ (1) Geoscience and Technology Division, CSIR-North East Institute of Science and Technology, Assam, India \\ (2) Department of Applied Geology, Dibrugarh University, Assam, India
}

Article history

Receveid August 3, 2017; acceptedFebruary 2, 2018.

Subject classification:

Mikir Hills; Kopili Fault; Bomdila Fault; Seismotectonics; Gravity contour; Magnetic contour.

\begin{abstract}
The Mikir Hills plateau is encompassed by two prominent faults - Bomdila Fault to the east and the Kopili Fault to the west characterized by strike-slip kinematics. The Kopili Fault has a dip of $75^{\circ}$ towards NE. Simultaneously, the Bomdila Fault dips with $50-55^{\circ}$ towards the NNE. An integrated approach based on seismotectonics, gravity and magnetic data is utilized to understand the tectonic activity of the Kopili and Bomdila Faults. The bottom of seismogenic zones is inferred to be $45 \pm 2 \mathrm{~km}$ and $50+2 \mathrm{~km}$ for the Kopili Fault and the Bomdila Fault region respectively. So far gravity anomaly is concerned; it varies between -110 to +60 mgals along the Kopili - Bomdila Fault regions from the Belt of Schuppen to the MCT. The low gravity values over the Bomdila Fault area indicate presence of thick alluvial deposits while along Kopili Fault lesser sediment thickness is observed. Simultaneously, basement being at shallower depth, lower magnetic values indicate presence of thick alluvial deposits in and around Bomdila Fault. The curvatures and closures of the gravity contours along the fault lines indicate structures involving basement and indicate influence of Bomdila Fault up to the basement. Simultaneously, it is observed that Kopili and Bomdila faults are neotectonically active. All these are the prime input to the seismic hazard assessment of the region.
\end{abstract}

\section{INTRODUCTION}

The Northeastern region (NER) of India is a seismically active region which lies in the most active zone $\mathrm{V}$ (BMTPC, 2003) (Figure 1a) of seismic zones of India. The region jawed in between the Himalayan collision arc to the north and northeast and the Indo Burmese subduction arc to the south and southeast has produced two great earthquakes (1897 and 1950) and the whole region experienced 20 large earthquakes $(M>7.0)$ during the last 200 years [Angelier and Baruah, 2009]. This region is tectonically divided into several mosaics by deep-rooted faults/thrust along which episodic block/thrust/strike-slip movements are reported [Nandy,
1986, 2001]. The seismicity pattern of NER shows relatively higher concentration of events in the Shillong and Mikir Plateaus, Arunachal Himalaya and IndoMyanmar subduction zone.

Amongst a number of active faults in NER, the Kopili and the Bomdila Faults are very active, which is evidenced from the occurrence of 24 large magnitude $\left(M_{w} \geq 5.5\right)$ seismic events in recent past (Figure $\left.1 \mathrm{~b}\right)$. Concentration of events along both the Kopili and Bomdila Faults are considered to be an intraplate seismotectonic domain. These intraplate seismic activities are fairly intense in this region due to its complex stress regime [Nandy, 2001, Angelier and Baruah, 2009]. The Kopili Valley region has produced two large earthquakes 


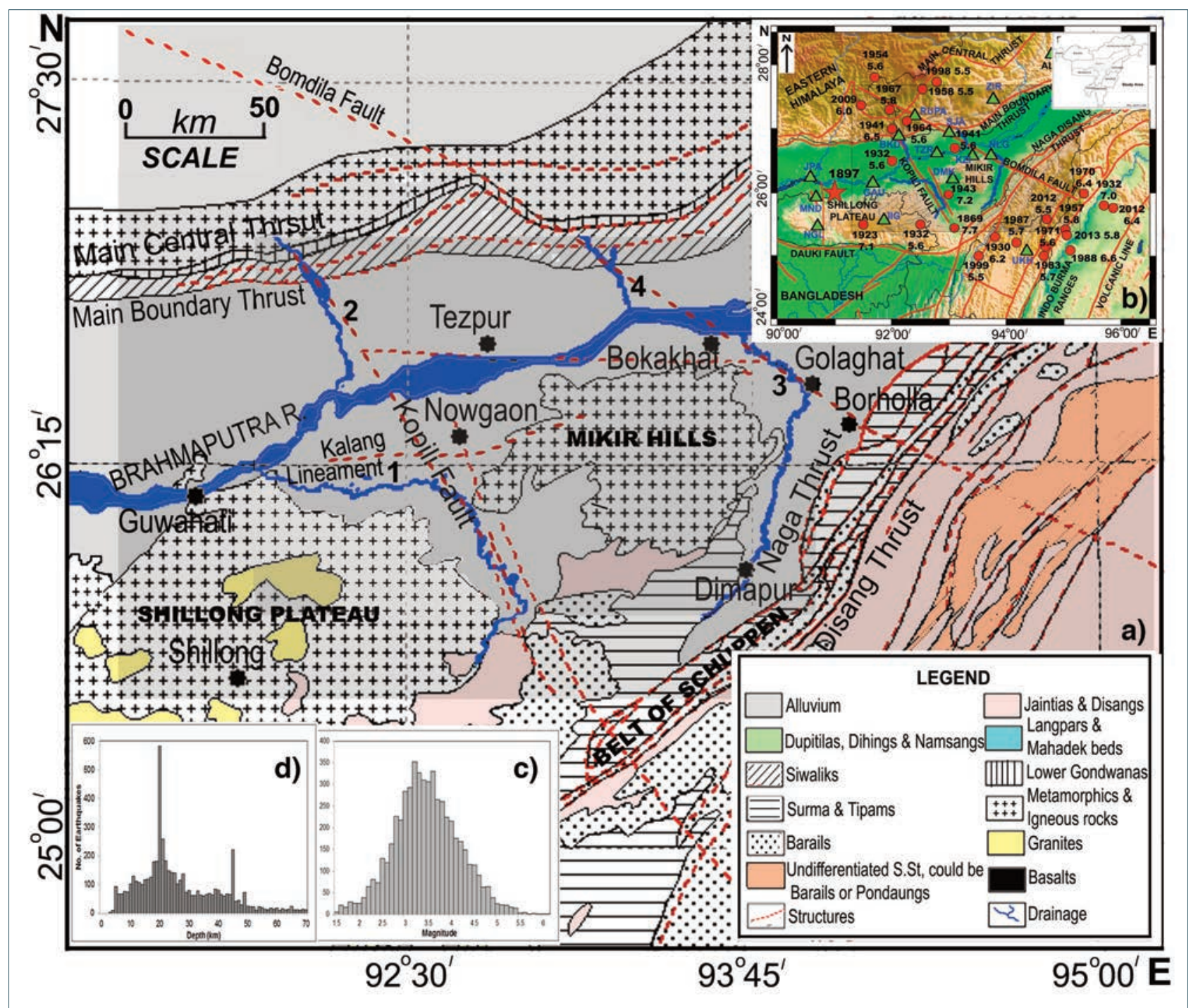

FIGURE 1. a) Geological location map of the study area (within latitudes $25^{\circ} 00^{\prime}-28^{\circ} 00^{\prime} \mathrm{N}$ and longitudes $91^{\circ} 00^{\prime}-96^{\circ} 00^{\prime} \mathrm{E}$ shaded in grey) showing the major structures (modified after Dasgupta, 1977 and Nandy, 2001). The major rivers along the study area are: 1. Kopili R., 2. Dhansiri (North) R., 3. Dhansiri (South) R. and 4. Bargang R. Inset: b) showing major earthquakes along with tectonic features (red lines) in Northeast India region (after Murthy, 1969; Nandy, 2001 and Baruah and Hazarika, 2008). The great 1897 Shillong earthquake (Ms 8.7) in the region is shown by star, and the large earthquakes $(\mathrm{Mw}>5.5)$ by circles. The digital seismic stations are shown by triangles. c) and d) are the frequency distribution of magnitudes and focal depths of 9376 earthquakes of Northeast India during the period 1984-2015.

(M>7.0) in 1869 and 1943 and Kopili Fault is thought to have triggered the 2009 Bhutan earthquake [Kayal et al., 2012] (Figure 1b). Kayal et al. [2006, 2010, 2012] have identified this region as a potential region of generating future large magnitude earthquakes. Recently, it is argued that Kopili Fault cuts across the Himalayas and caused displacement and curvilinear structure at the Main Boundary Fault and Main Central Thrust zones [Kayal et al., 2010, 2012]. It is also observed that topographic features (e.g., higher hillocks, valleys, rivers and elevation) represent a departure from hydrostatic equilibrium, and earth's reaction to surface load according to certain rheological laws provide a means of distributing the stress over depth within the earth [Nandy,
2001]. From historical point of view, the first estimate of stress in the earth was based on gravity anomalies. Gravity anomaly also infers that there exist mass anomalies and, therefore, deviatoric stresses, that are unrelated to the surface elevations [Mc Nutt, 1980]. Gravity modeling generally uses density variation, whereas magnetic uses susceptibility contrast to map basement depth [Ghosh et al., 2010].

Seismological work in these areas are done by Nandy [2001], Dasgupta [1977], Dasgupta et al., [1987], Kayal [1987, 1996, 2001], Kayal et al., [2006, 2010, 2012], Baruah et al., [1997], De and Kayal [2004], Bhattacharya et al., [2002, 2008, 2010]. Paleoseismic investigation in the Kopili Fault zone by Kumar et al. [2016] 
indicates seismogenic liquefaction features near Kopili and Kalang rivers which correspond to the occurrence of causative seismic events. Gravity and magnetic studies in different parts of northeast India was done by Verma and Mukhopadhyay [1977], Tiwari et al. [2006], Saha et al. [2008], Ghosh et al. [2010], Saha [2011] and Sharma et al. [2012].

This study deals with seismotectonics, gravity and magnetic data to understand the dynamics of the Kopili, Bomdila Faults and its vicinity. The variation of gravity and magnetic anomaly besides inferences on focal mechanism solutions, orientation of $\mathrm{P}$ \& $\mathrm{T}$ axis and the primary faults planes are the main inputs which ascertains the dynamics associated. The major question addressed is that these two faults are seismically and neotectonically active and are capable of producing a >M7.0 earthquake. Moreover these two faults intersect with one gigantic tectonic domain - the Main Boundary Thrust in Arunachal Himalaya. A critical assessment of these interactions and their persistent associated features are the major issues addressed in this study. The inferences from this study is that these two faults show recent tectonic activity to the east of Kopili Fault and west of Bomdila Fault, and is a region of stress build up with high strain of about $(64-256)^{*} 10^{-9}$ nanostrain/year [Kreemer et. al., 2003]. Hence, these two faults and its vicinity are seismically a potential site of a future large earthquake.

\section{TECTONIC SETTING}

Geologically, the Kopili and Bomdila Faults comprise Neogene-Quaternary sediments, which were deposited directly over the Archean basement. The Kopili Fault zone is approximately $300 \mathrm{~km}$ long and $50 \mathrm{~km}$ wide. It is a NW-SE trending strike-slip fault [Kayal et al., 2006, Bhattacharya et al., 2008, 2010]. The tectonic disposition of this fault delineates the two Precambrian massifs on either side - the Shillong Plateau and the Mikir Hills. It is bounded by the Main Boundary Thrust (MBT) to the north and by the NE-SW trending Belt of Schuppen to the south (Figure 1a). The Bomdila Fault trends along WNW-ESE direction and is about $400 \mathrm{~km}$ long strike slip fault. The northern part of the fault mostly lies in the Gondwana, Paleogene and Neogene sediments. This fault is bounded to the east and south by the Belt of Schuppen, to the west by the Mikir massif. In the north, the fault also cuts across the Himalayan fold belt [Nandy and Dasgupta, 1991].

The Kopili and the Bomdila Faults are the two main seismically active structures under study. The Kopili
Fault was the seat of two large earthquakes (Figure 1b). One of these events occurred on 1869 (M 7.7) in the southeastern end of the fault transgressing Naga-Disang thrust while the other event (1943; M 7.2) occurred farther north of 1869 event within a span of about 75 years [Kayal, 2008] (Figure 1b). Intense seismic activity is observed down to a depth of about $50 \mathrm{~km}$ beneath the Kopili Fault, and the activity continues to the Main Central Thrust (MCT) in the Bhutan Himalaya. Although MCT is dormant [Ni and Barazangi, 1984], however intense activity is observed at the region where Kopili Fault meets the MBT and MCT [Nandy, 2001, Kayal et al., 2010, 2012]. This is evidenced by the August 19, 2009 Earthquake (Mw 5.1) in the Assam Valley that occurred in the center of the Kopili Fault zone and the September 21, 2009 strong Bhutan Himalaya Earthquake (Mw 6.3) that occurred at the northern end of the Kopili Fault where it hits the MCT [Kayal et al., 2012]. The earthquakes of August 19, 2009 and the September 21, 2009, are shallow focus (depth $\sim 10 \mathrm{~km}$ ) showing right lateral strike-slip faulting [Kayal et al., 2010]. This indicates that the Kopili Fault zone is under compressional stress from the Indo-Burma arc to the east and from the Himalayan arc to the north and is characterized by transverse tectonics. The Bomdila Fault lies in a tectonically active region which crisscrosses the MCT, MBT and Naga-Disang thrust along NW-SE direction. Most of seismic events that occur along this fault have shallow focus depth [Kayal, 2008], except for a few events in the NW trending wedge-shaped block lying in between the Kopili and the Bomdila Faults. The earthquake events in this tectonic block occur in a diffused pattern having post-collisional intracratonic characteristics [Nandy and Dasgupta, 1991]. Characteristically, the Upper Brahmaputra Valley between the Bomdila Fault and almost near NW-trending Mishmi Thrust in the northeast is almost devoid of any earthquakes, which is termed as the Assam Gap [Khattri, 1983].

\section{DATA SELECTION AND METHODOLOGY}

A database of 9376 events consisting of hypocentral parameters and 188 focal mechanism solutions (FMS) are prepared for the periods 1984-2015 and 1963-2015, respectively for seismotectonic study. The hypocentral database is prepared from the seismological bulletin published annually by CSIR North East Institute of Science and Technology (NEIST)-Jorhat and CSIR National Geophysical Research Institute (NGRI)-Hyderabad. Phase data bulletins of Indian Meterological Department (IMD), Shillong, Manipur University, Mizoram University and 


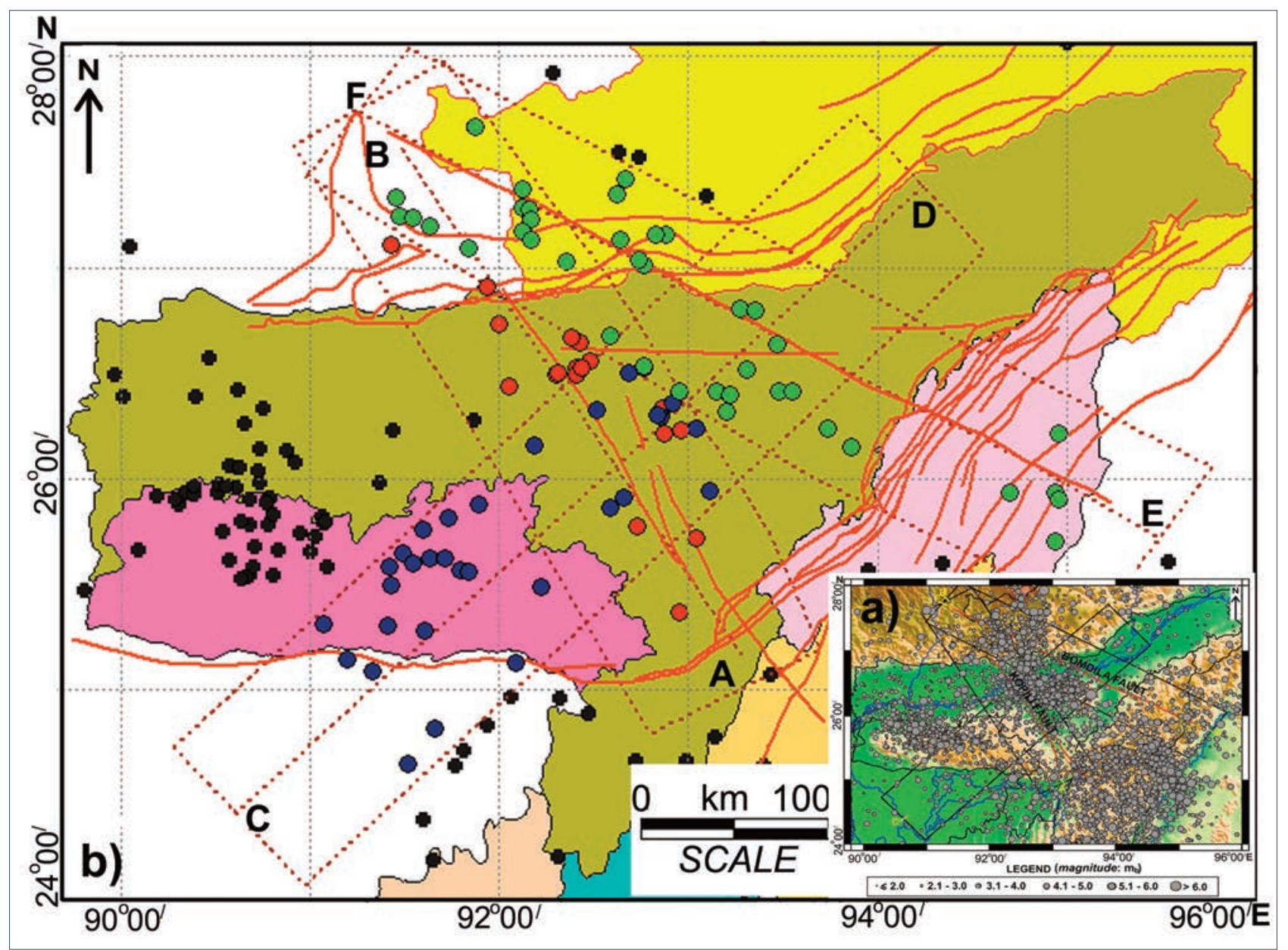

FIGURE 2. a): Inset: Seismotectonic map of the Kopili-North Dhansiri and South Dhansiri-Bargang Valleys. AB is the section along the Kopili Fault, EF is the section along the Bomdila Fault and CD is the section across the Kopili and Bomdila Faults. The bounding lines indicate a distance of $50 \mathrm{~km}$ on either side of the section lines. b) Structural map of the study region showing distribution of 188 numbers of Focal Mechanism Solutions (black and coloured circles) within latitudes $24^{\circ}-28^{\circ} \mathrm{N}$ and longitudes $90^{\circ}-96^{\circ} \mathrm{E}$. The dashed brown lines indicate the sections lines. AB is the section along the Kopili Fault (FMS shown by red circles), CD is the section across the Kopili and Bomdila Faults (FMS shown by blue circles) and EF is the section along the Bomdila Fault (FMS shown by green circles).

Gauhati University are also taken into consideration wherever needed. The barest minimum magnitude of the earthquake events are considered to be 1.5.

The uncertainties involved in the estimates of origin time for these events are 0.03 to $0.1 \mathrm{sec}$. The uncertainties involved in the estimates of focal depths are $\pm 3 \mathrm{~km}$. On the other hand the uncertainties involved in the estimates of longitude (ERLN) and latitude (ERLT) of epicenters lies within the range of 0 to $2.0 \mathrm{~km}$. The maximum number of earthquakes lies within the magnitude band of $2.5-5.5$, which is around $80 \%$ (Figure 1c). As regards distribution of depth, most of the events occur within the depth of $50 \mathrm{~km}$ range (Figure 1d).

The FMS database is prepared from Global Centriod Moment Tensor (GCMT) (http://www.globalcmt.org) and published literatures [Chen and Molnar, 1990, Kayal et al., 2012 and Nandy, 2001]. Five events of $12^{\text {th }}$ May 2012 (M 5.4) obtained from and recorded by more than 5 local seismic stations of CSIR-NEIST have been located using the HYPOCENTER program of Lienert et al. [1986] with an average RMS $0.03 \mathrm{sec}$, epicenter and depth error $<1 \mathrm{~km}$. FMS for these events are determined using FOCMEC (http://www.iris.edu/pub/programs/focmec/).

In order to correlate, the FMS and depth section plots within a span of $50 \mathrm{~km}$ on either side along and across the Kopili and Bomdila Faults, three sections are considered:

(a) Kopili Fault (section AB; $25.18^{\circ} \mathrm{N}, 93.27^{\circ} \mathrm{E}-27.58^{\circ}$ $\mathrm{N}, 91.48^{\circ} \mathrm{E}$ ), parallel to the trend of the fault.

(b) Kopili - Bomdila (section CD; $24.42^{\circ} \mathrm{N}, 90.60^{\circ} \mathrm{E}$ $27.38^{\circ} \mathrm{N}, 94.23^{\circ} \mathrm{E}$ ), perpendicular to the trend of the faults and

(c) Bomdila Fault (section EF; $25.73^{\circ} \mathrm{N}, 95.48^{\circ} \mathrm{E}-$ $27.75^{\circ} \mathrm{N}, 91.25^{\circ} \mathrm{E}$ ), parallel to the trend of the fault.

A total number of 1159, 1213 and 1160 events of M>1.5 along Kopili Fault, across Kopili-Bomdila and 
a) i.

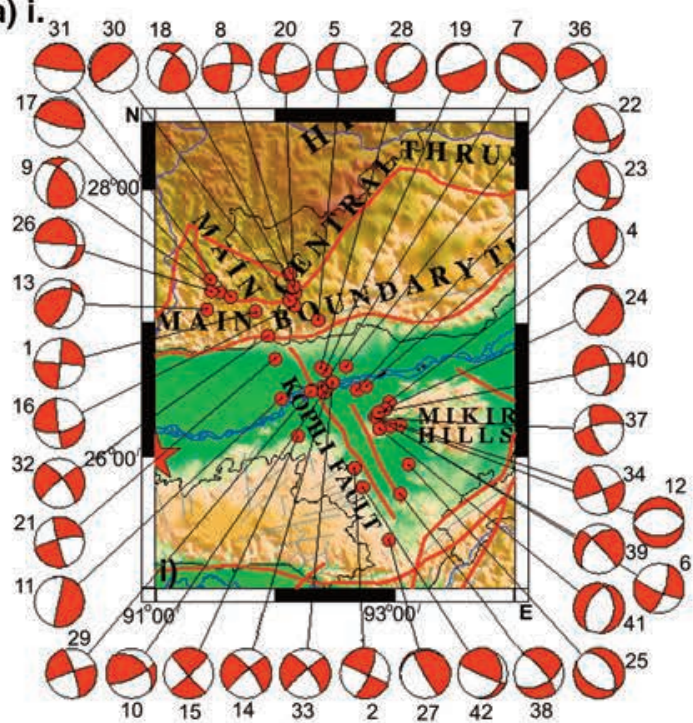

b) i. $\quad \overbrace{}^{23} \overbrace{}^{30}$

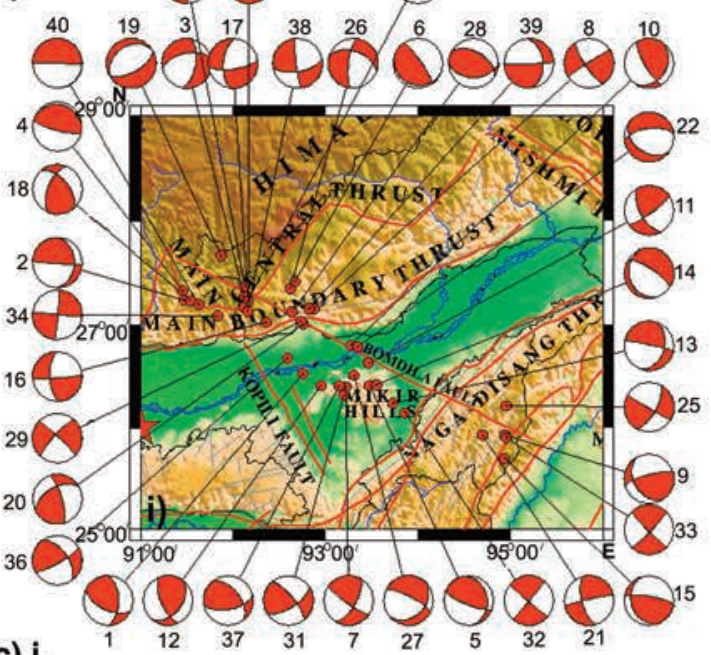

c) $\mathbf{i}$.

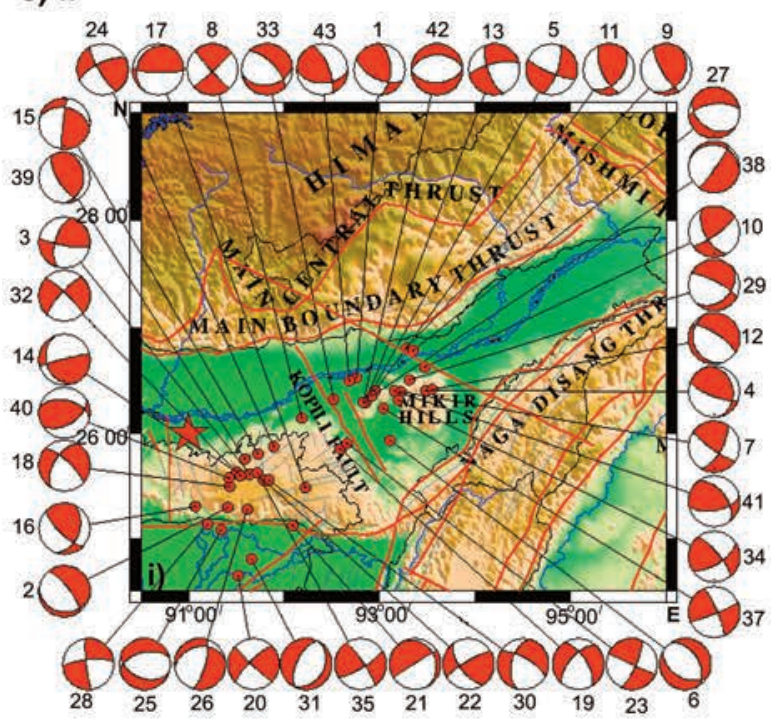

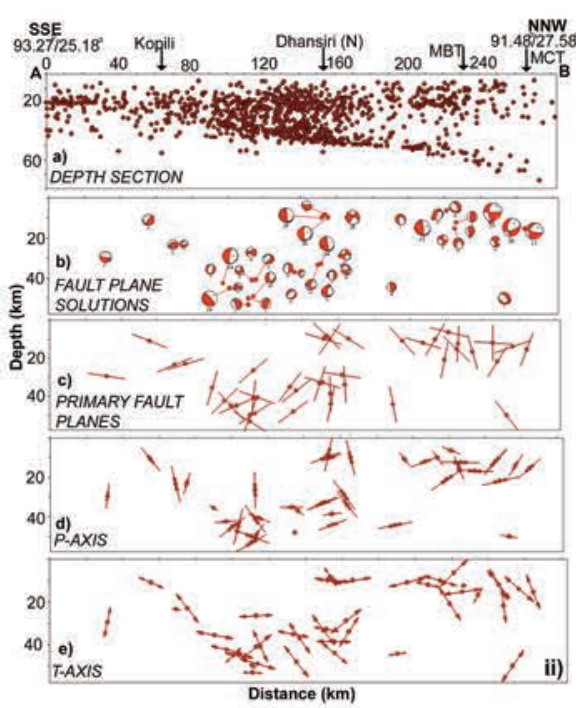

Arunachal
95

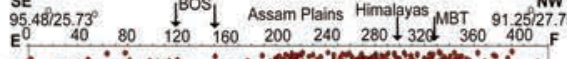

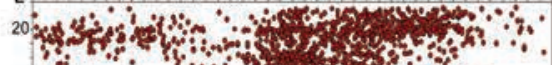

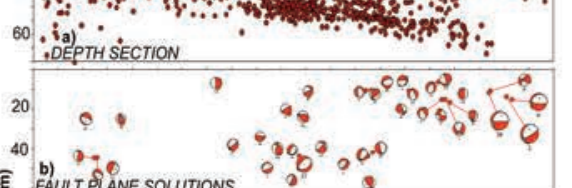





PRIMARYFAULT PLANES

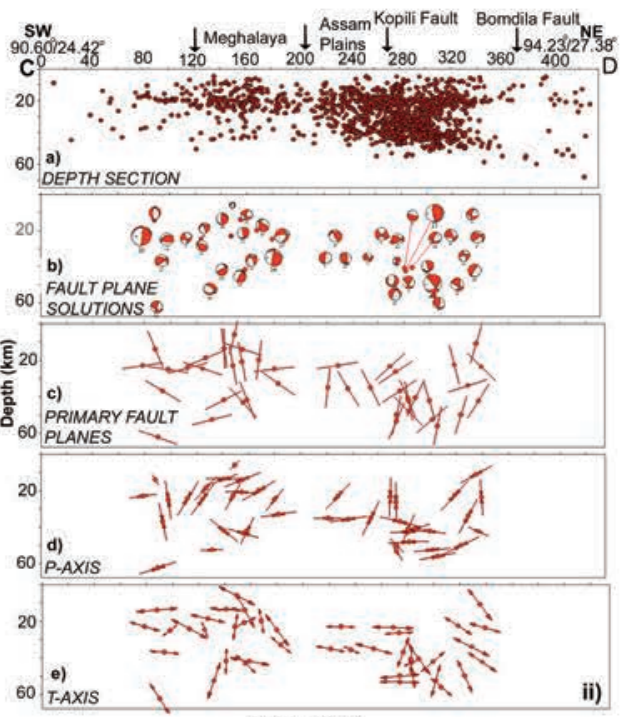

FIGURE 3. Focal Mechanism Solutions (FMS) of the earthquake events using P-wave first motion and data compiled from various sources a)i. 40 events along the Kopili Fault (A-B), b)i. 39 events along the Bomdila Fault (E-F) and c)i. 42 events occurring across the Kopili and the Bomdila Faults. a), b) and c) ii Illustrates a) the depth distribution of events, b) projected depth view of focal mechanism solutions, c) nodal planes projected in the depth section and d) and e) orientation of $\mathrm{P}$ and $\mathrm{T}$ axes, along section $\mathrm{AB}, \mathrm{EF}$ and $\mathrm{CD}$ respectively. 
across Bomdila Fault are plotted respectively. Out of these, a total number of 42 FMS along the Kopili, 43 FMS across Kopili-Bomdila and 40 FMS along Bomdila Fault are considered. Cross-sections of these events are plotted [utilizing RAKE software; Louvari and Kiratzi, 1997] with the variation of hypocenters, depth view of focal mechanism solutions, plots of the primary fault planes, P-T axes with respect to the depth to know about the dynamics underneath.

For a better understanding of structures and tectonics of a region, it is essential to have an insight into the deep crust down to the upper mantle. One of the tools for drawing such inferences is the analysis of the gravity and magnetic data especially in the area covered by thick sediments. A detailed gravity and magnetic data are compiled from GRACE satellite by USGS (https://grace.jpl.nasa.gov/data/) to observe gravity and magnetic anomaly associated with major tectonic elements in the region. This anomaly supplements the seismotectonics analysis of this region. GRACE measure changes of gravity and magnetic field in time and register mass movements caused by global and regional changes. Also literature data and maps by different workers on geophysical gravity studies are compiled [e.g. Verma and Mukhopadhyay, 1976, 1977; Nandy, 2001; Tiwari et al., 2006; Saha et al., 2008; Ghosh et al., 2010; Saha, 2011; Vaish and Pal, 2015] and a thorough study is done to find out evidence which support the findings.

Geomorphologically, various features including disposition of the faults and the main trends of some major rivers trunks (Kopili-Dhansiri (N) and Dhansiri (S)-Bargang) are parallel to the main fault trends (KopiliBomdila). The anomalous linear courses and the abrupt right angle turn in many places of the rivers indicate relatively some influence of these structures on the regional drainage of the area. Moreover, geomorphological evidences like, development of terraces, upliftment, tectonic depressions, sag ponds, swamps, fault scarps, drainage anomalies and abandoned channels along the faults suggest that these two faults are highly active. In addition the disposition of the gravity and the magnetic contours clearly depicts the trend of these two faults which can be traced from the Belt of Schuppen upto MCT through these rivers.

\section{RESULTS}

The significant indicator of ongoing tectonic activity in the Kopili and the Bomdila Faults is derived from seismotectonic, gravity and magnetic studies supple- mented by neotectonic evidence. The important parameters which incidentally discover the internal mechanism, its coupling, the anomalous tectonic behavior besides defining crustal structure are:

\subsection{SEISMOTECTONIC STUDY 4.1.1 KOPILI FAULT:}

The epicentral map indicates that the Kopili Fault remains highly active towards northern part in comparison to the southern part (Figure 2a). The seismic activity of the region to the north where the Kopili Fault intersects MBT and MCT portray current tectonic activity. It is also observed that the seismicity in the eastern part of the fault is more frequent than in the western part (Figure 2a).

In order to study the source characteristics of the Kopili Fault region, a total number of 40 fault plane solutions along the section $\mathrm{AB}$ are used (Figure 3a,i). However among these focal mechanism solutions (Figure 3a,i), different types of mechanisms are observed (Thrust $=5$, Thrust with strike-slip component $=4$, Strike-slip $=23$, Normal $=1$, Normal with strike-slip component $=6$ ) in the demarcated area. A total of 10 (event number 1, 32, 21, 29, 10, 14, 2, 27, 42 and 38) focal mechanism solutions could be associated with the Kopili Fault. Out of these, 7 (event numbers 1, 32, 21, 29, 14, 2 and 38) events are characterized by strike-slip faulting, 2 (event numbers 10 and 42) are characterized by thrust with strike-slip component events and 1 event (event number 27) indicate thrust component. Event number 29 characterizes the Kopili Fault with strike-slip mechanism having the fault plane very clearly oriented along NW-SE. Similarly event numbers 2, 14, 38, 32 clearly ascertain the trend of the fault plane which is pertinent to the regional trend of the Kopili Fault. Similar strike-slip type faulting mechanisms are also observed far north where Kopili Fault crosses the MBT. Further north, in the same alignment of the Kopili Fault, crossing the MCT, the region is characterized by preferably thrust mechanisms as depicted by event numbers 31 and 17 .

Considering the primary nodal planes of the 10 fault plane solutions which coincide with the regional NW-SE trend of the Kopili Fault, it is observed that the fault dips towards the NE direction with an average dip angle around $75^{\circ}$. For example, two solutions numbered 33 and 29 are well associated with the Kopili Fault. The solution 33 indicates the focal parameters as strike $=321^{\circ}, \operatorname{dip}=73^{\circ}$, rake $=173^{\circ}$, while solution 29 indicate strike $=342^{\circ}$, dip $=80^{\circ}$, rake $=-175^{\circ}$. These parameters and a few solutions involve predominantly the strike-slip mechanisms of the Kopili 
Fault having dip angle $\sim 75^{\circ}$ to the NE.

Figure 3a,ii illustrates the distribution of events along the Kopili Fault (section AB in Figure 2a). The depth section indicates very clearly the variation of focus between $40 \mathrm{~km}$ and $75 \mathrm{~km}$ from southeast to northwest which comprises mainly Kopili Fault, MBT and MCT, successively. Notably, the bottom of seismogenic zone is within $45 \pm 2 \mathrm{~km}$ in the Kopili where large concentrations of earthquakes are observed. However, sharp increase in depth is observed starting from north of Brahmaputra towards north up to MCT (Figure 3a,ii,a). The projected depth view of the FMS (Figure 3a,ii,b), the inferred primary fault plane (Figure 3a,ii,c), orientation of $\mathrm{P}$ and $\mathrm{T}$ axes (Figures 3a,ii,d,e) in Kopili depict the characteristics of each of associated focus.

\subsubsection{BOMDILA FAULT:}

Similarly, the epicentral map during 1984-2015 illustrates less seismicity in and around Bomdila Fault in comparison to the Kopili Fault zone (Figure 2a). However, the segment of the fault beyond the MCT towards north does display a clustering of events. This shows that the Bomdila Fault remains highly active towards northern part in comparison to the southern counterpart. It is seen that the seismicity in the western part of the Bomdila Fault is much higher as compared to the eastern part. Most of the seismic events that occur along this fault have shallow focus depth [Kayal, 2008] except for a few events in the NW trending wedge shaped block lying in between the Kopili and the Bomdila Faults.

A total number of 39 fault plane solutions have been used for source characteristics of the Bomdila Fault (Figure 3b,i). Figure 3b,ii illustrates the distribution of events along the section EF which are used to study the Bomdila Fault from south to north. However among these focal mechanism solutions (Figure 3b,i), different types of mechanisms characterize (Thrust $=3$, Thrust with strike-slip component $=10$, Strike-slip $=23$, Normal $=1$, Normal with strike-slip component $=2$ ) the area demarcated. A total of 12 (event numbers 32, 9, 11, 22, 10, 20, 28, 27, 3, 23, 29 and 17) of FMS could be associated with the Bomdila Fault. Out of these, 9 (event numbers 32, 9, 11, 20, 28, 3, 23, 29 and 17) events are characterized by strike-slip faulting; besides 2 (event numbers 10 and 27) events having thrust with strike-slip component and 1 event (event number 22) showing normal with strike-slip component. The strike-slip events clearly ascertain the trend of the fault plane which is pertinent to the regional trend of the Bomdila Fault. Con- sidering the primary nodal planes of the 12 fault plane solutions lying close to the Bomdila Fault, which coincide with its regional NW-SE trend, it is observed that the fault dips towards the NNE. For example, two solutions numbered 30 and 26 are well associated with the Bomdila Fault. The solution for number 30 indicates the focal parameters as strike $=315^{\circ}, \operatorname{dip}=53^{\circ}$, rake $=26^{\circ}$ and solution for number 26 indicates strike $=290^{\circ}$, dip $=50^{\circ}$, rake $=-160^{\circ}$. These parameters and a few solutions involve predominantly with the strike-slip characteristic of Bomdila Fault having dip angle 50-55 to the NNE.

Simultaneously, Figure 3b, ii illustrates the distribution of events along the section EF (Figure 2a) aligning the Bomdila Fault. The depth section indicates very clearly the variation of focus from 40 to $65 \mathrm{~km}$ from south to north, which comprises Belt of Schuppen, Assam Plains, Arunachal Himalayas and MBT. Notably, the bottom of the seismogenic zone is within $50 \pm 2 \mathrm{~km}$ beyond Belt of Schuppen where large concentration of earthquakes is observed towards north (Figure 3b,ii,a). However, sharp increase in depth starts from Arunachal Himalayas towards further north. The depth section plots of fault plane indicate the characteristics orientation of the plane co-located with the focus. The projected depth view of the FMS (Figure 3b,ii,b), the inferred primary fault plane (Figure $3 b, i i, c)$ and orientation of $\mathrm{P}$ and $\mathrm{T}$ axes (Figures 3b,ii,d,e) show dominant NW-SE trending Paxes in the Bomdila Fault while the T-axes are mostly oriented along NNW direction. The orientation of Paxes conforms and confirms the transverse tectonics of Bomdila Fault.

\subsubsection{ACROSS KOPILI-BOMDILA FAULTS:}

A total number of 42 fault plane solutions are used to study the source characteristics across both the Kopili and Bomdila Faults (Figure 2a), as illustrated in Figure 3c,i. Different types of mechanisms (Figure 3c,i), are observed among these focal mechanism solutions (Thrust with strike-slip component = 10 , Strike-slip $=21$, Normal $=2$, Normal with strikeslip component $=9$ ).

Figure 3c,ii illustrates the depth section of events distributed along the section CD (Figure 2a) across the Kopili and the Bomdila Faults. The depth section (Figure 3c,ii,a) indicates very clearly the variation of focus from $40 \mathrm{~km}$ to $60 \mathrm{~km}$ along section CD (from west to east) which comprises Shillong Plateau, Assam Valley, Kopili and Bomdila Faults. Seismicity is seen to be relatively lower at and to the east of the Bomdila Fault. The bottom of seismogenic zone is 


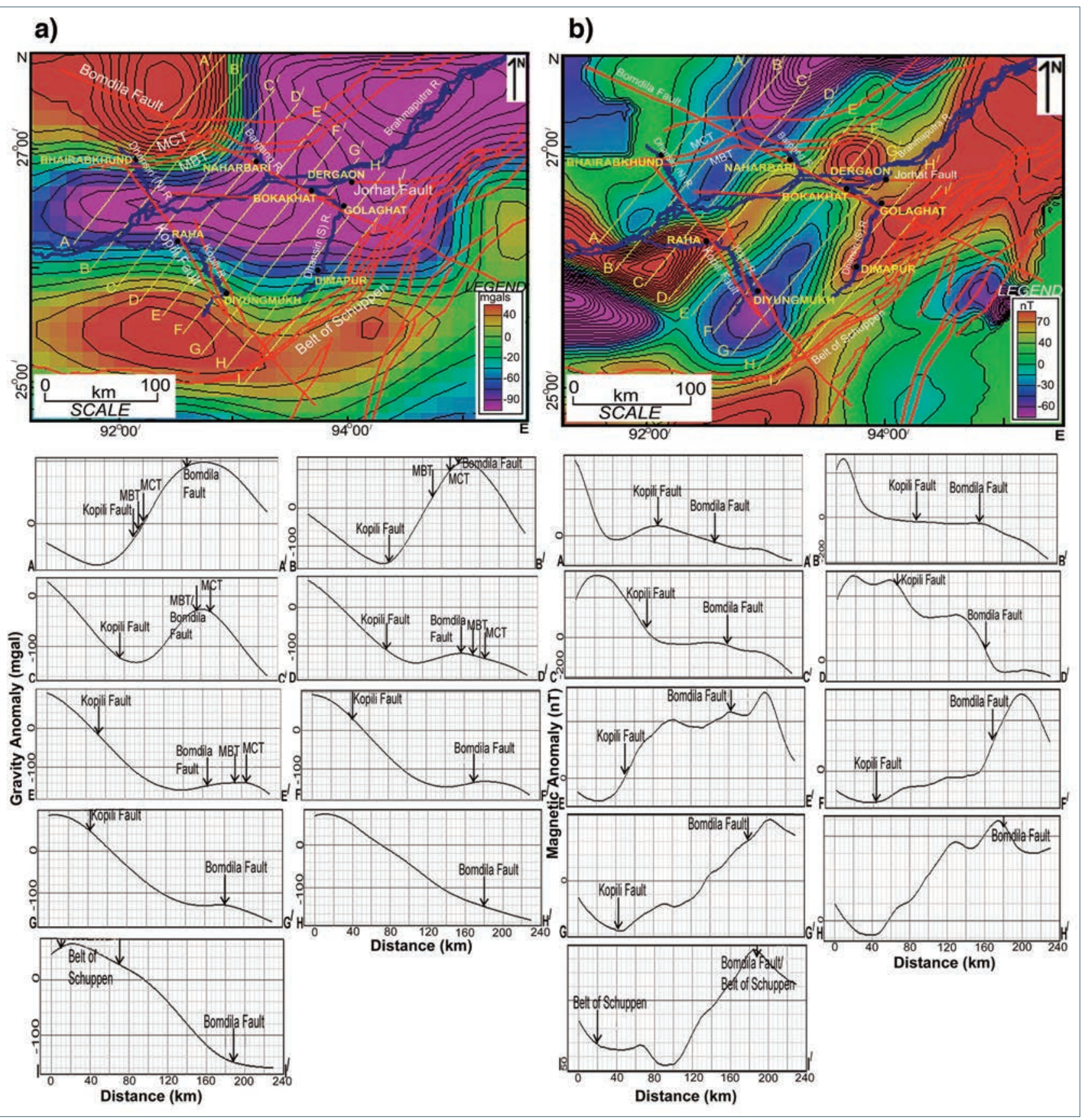

FIGURE 4. a) and b): Gravity and magnetic anomaly map at 20 mgal contour intervals derived from Grace Satellite showing the Kopili and the Bomdila Faults. The red lines indicate the geological structures and the blue lines indicate the major rivers under study. The yellow lines $\left(\mathrm{AA}^{\prime}, \mathrm{BB}^{\prime}, \mathrm{CC}^{\prime}, \mathrm{DD}^{\prime}, \mathrm{EE}^{\prime}, \mathrm{FF}^{\prime}, \mathrm{GG}^{\prime}, \mathrm{HH}^{\prime}\right.$ and $\left.\mathrm{II}^{\prime}\right)$ are the gravity and the magnetic profile lines across the Kopili and the Bomdila Faults respectively.

within $45 \pm 2 \mathrm{~km}$ in the Kopili which increases towards the Bomdila Fault, consequently. In this illustration as well, a large concentration of earthquakes are observed in the Kopili Valley area. The projected depth view of the focal mechanisms (Figure 3c,ii,b), the inferred primary fault plane (Figure $3 c, i i, c)$ and orientation of $\mathrm{P}$ and $\mathrm{T}$ axes (Figure 3c,ii,d,e) show dominant NNW and NNE trending pressure axes in both Kopili and Bomdila while the T-axes are mostly oriented along E-W and NW-SE direction.

\subsection{GRAVITY STUDY:}

\subsubsection{GRAVITY ANOMALY IN AND AROUND KOPILI FAULT:}

The gravity contours of the area range from -110 to 60 mgals and almost follow the regional structural trend of the region (Figure 4a). The gravity contours along the western part of the Kopili Fault trend in the E-W direction. But in the central part of the fault i.e., towards the Brahmaputra and in the southwestern part (near the fault end) we observe gravity anomaly which 
may indicate some structures or anisotropic material involving the basement (Figure 4a). The 20 mgals interval contour indicates a higher thickness of alluvial deposit across Kopili and Bomdila Faults along the Bramhaputra flood plain. The whole Brahmaputra Valley show a low value of -70 to -110 mgals while the value increases towards both the northern and southern side of the Brahmaputra Valley up to +40 mgals. To the southern side of the Brahmaputra River (along the Kopili Fault), the contours trend from an E-W direction to a NW-SE direction (Figure 4a). While in the northern side of the Brahmaputra River, the contours trend in an E-W direction. The contours to the north of the Kopili Fault are more closely spaced by. The steeper gradients suggest faulting up to the basement and maximum change in crustal thickness [Verma and Gupta, 1973]. The sparse distribution of average normal gravity estimates in the central part of the Kopili Fault is due to the thick deposit of alluvium. Here the basement assumes a north dipping bowl shaped basin with thickest sediment in the area north of Nagaon. The NW-SE Kopili Fault is clearly discernible by the disposition of these gravity contours. The contour show deviation from the average normal gravity estimates where the fault passes through. The gravity profiles $\left(\mathrm{AA}^{\prime}, \mathrm{BB}^{\prime}, \mathrm{CC}^{\prime}, \mathrm{DD}^{\prime}, \mathrm{EE}^{\prime}, \mathrm{FF}^{\prime}, \mathrm{GG}^{\prime}, \mathrm{HH}^{\prime}\right.$ and $\left.\mathrm{II}^{\prime}\right)$ in Figure $4 \mathrm{a}$ across the Kopili Fault indicate low gravity value along the fault. But the value increases as we move from the north to the south of the fault indicating less sediment thickness (shallow basement) as we approach the Belt of Schuppen area.

\subsubsection{GRAVITY ANOMALY IN AND AROUND BOMDILA FAULT:}

The gravity contour varies in between -110 mgal to +60 mgal over the Bomdila Fault (Figure 4a). Towards the northern and the southern end of the fault they show closely spaced contours with U-shaped pattern. The gravity contours around Golaghat are low which range from -110 to -20 mgals. The curvatures and the closures by the sides of the fault indicate some structures involving basement or may be due to the influence of the Bomdila Fault, which extends down to the basement. Around $26^{\circ} 20^{\prime} \mathrm{N}$ latitude and $94^{\circ} 00^{\prime} \mathrm{E}$ longitude, where the Bomdila Fault meets the Belt of Schuppen, the contours takes sharp southward turn with steeper gradient (Figure 4a). This indicates that the northeast extension of the basement complex (foreland spur) plunges sharply near to the area where the Bomdila Fault meets the Belt of Schuppen as inferred by Nandy [2001]. Increase in gravity value, steep gradient and flexure of the contours near the northern end of the Bomdila Fault may be due to a deep seated fault located south of the Himalayan Frontal Thrust [Nandy, 2001]. This may also suggest the extension of the Bomdila Fault up to the basement. Small local partial closures to the west of Bokakhat may indicate local sag in the basement. This area is a part of the Kaziranga National Park. Low gravity value over this area is due to the presence of thick alluvial deposits, which progressively become thinner towards NW and SE of the Bomdila Fault. It is observed that the trend and the gradient of the gravity contours follow the trend of the Bomdila Fault. The gravity profiles $\left(\mathrm{AA}^{\prime}, \mathrm{BB}^{\prime}\right.$ and $\left.\mathrm{CC}^{\prime}\right)$, in Figure $4 \mathrm{a}$ across the Bomdila Fault indicate higher gravity value along the Bomdila Fault than in the Kopili Fault indicating lesser sediment thickness in this area. But profile lines $\mathrm{DD}^{\prime}, \mathrm{EE}^{\prime}$, $\mathrm{FF}^{\prime}, \mathrm{GG}^{\prime}, \mathrm{HH}^{\prime}$ and $\mathrm{II}^{\prime}$ (Figure 4a) indicate lower gravity values in the Bomdila Fault than in Kopili Fault which indicates that the sediment thickness increases towards south along the Bomdila Fault. From Naharbari towards Golaghat and beyond, the value of gravity decreases indicating presence of thick sediment thickness around Golaghat.

\subsection{MAGNETIC STUDY:}

\subsubsection{MAGNETIC ANOMALY IN AND AROUND KOPILI FAULT:}

The values of the magnetic anomaly map along the Kopili Fault range from -80nT to +90 nT (Figure 4b). From the MCT along the Kopili Fault, the magnetic value change from a positive value of $+50 \mathrm{nT}$, reaching a very high value of $+80 \mathrm{nT}$ near Raha to a negative value of $-80 \mathrm{nT}$ at the southeastern end of the fault (Figure $4 \mathrm{~b})$. The value rises again in the Belt of Scuppen indicating highly susceptible material underlying the places where we find high magnetic anomalies. From the profiles $\mathrm{AA}^{\prime}, \mathrm{BB}^{\prime}, \mathrm{CC}^{\prime}, \mathrm{DD}^{\prime}, \mathrm{EE}^{\prime}, \mathrm{FF}^{\prime}, \mathrm{GG}^{\prime}, \mathrm{HH}^{\prime}$ and $\mathrm{II}^{\prime}$ drawn across the Kopili Fault it is seen that from MCT up to Raha shown by profiles $\mathrm{AA}^{\prime}, \mathrm{BB}^{\prime}, \mathrm{CC}^{\prime}$ and $\mathrm{DD}^{\prime}$, the magnetic value is positive indicating shallower basement. On the other hand the profiles $\mathrm{EE}^{\prime}, \mathrm{FF}^{\prime}, \mathrm{GG}^{\prime}$ and $\mathrm{HH}^{\prime}$ show lower magnetic value indicating deeper basement.

\subsubsection{MAGNETIC ANOMALY IN AND AROUND BOMDILA FAULT:}

The anomaly contour map of the Bomdila Fault area show magnetic value from $-80 \mathrm{nT}$ to $+90 \mathrm{nT}$ (Figure 4b). We observe magnetic high to the east of the Bomdila fault and to the west of the Kopili fault along Bramhaputra flood plain while magnetic low is observed near Diyungmukh. Mixed magnetic anomaly prevails within 




FIGURE 5. Map showing the topography of the study area (topmost) along profile CD having the relationship among a) the average elevation profile, b) the depth view of the seismicity, c) gravity and d) magnetic profiles across the Kopili and Bomdila Faults.

the region encompassed by both the faults right from Naharbari to Dimapur and Bokakhat to Raha. This trend clearly indicates the presence of the NW-SE Bomdila Fault. The presence of the positive and negative anomalies on either side of the Bomdila Fault along with the trend of the magnetic contours indicates large crustal heterogeneities in the area. Profile lines $\mathrm{AA}^{\prime}, \mathrm{BB}^{\prime}, \mathrm{CC}^{\prime}$, $\mathrm{DD}^{\prime}, \mathrm{EE}^{\prime}, \mathrm{FF}^{\prime}, \mathrm{GG}^{\prime}, \mathrm{HH}^{\prime}$ and $\mathrm{II}^{\prime}$ in Figure $4 \mathrm{~b}$ drawn across the Bomdila Fault show that the fault from MCT to MBT (profiles $\mathrm{AA}^{\prime}, \mathrm{BB}^{\prime}$ and $\mathrm{CC}^{\prime}$ ) has lower magnetic values indicating greater sediment thickness. From MBT towards the Belt of Schuppen, positive magnetic value is observed all along the Bomdila Fault indicating the presence of susceptive materials and basement at shallower depth.

The average elevation along the profile $\mathrm{CD}$, the seis- micity depth section plot, gravity and magnetic anomalies are combined to develop a model of the structure underneath (Figure 5). The computed gravity anomaly in Shillong Plateau is comparatively higher than Mikir Plateau. This leads us to infer that Moho is located at shallower depth in Shillong Plateau and at deeper depth in Mikir Plateau respectively. This contrast is reflected prominently in magnetic anomaly throughout the profile where ( $\mathrm{FF}^{\prime}$ and $\left.\mathrm{GG}^{\prime}\right)$ we observe lower magnetic anomaly. Considering the relationship between the gravity, magnetic and seismicity, the higher gravity anomaly is due to presence of high density contrast. The occurrence of less seismicity confirms as well the presence of high density and rigid material. It is also assumed that the occurrence of seismicity is restricted to the upper to lower crustal domain far above Moho.

\subsection{NEOTECTONIC EVIDENCES:}

\subsubsection{KOPILI FAULT:}

The neotectonic activities in and around Kopili fault are characterized by: i) anomalous linear courses of two major rivers (Kopili and the Dhansiri (N) Rivers), ii) development of large number of low lands in later period [1971], and iii) development of kinks on existing structures like MCT and Belt of Schuppen. Such evidence as illustrated in Figure 6a indicate that the Kopili Fault is neotectonically active and is responsible for the existing regional landform and drainage trends in this area. Moreover, this fault can be traced from the Belt of Schuppen along the Kopili River and the Dhansiri (N) River up to the MCT.

\subsubsection{BOMDILA FAULT:}

Bomdila Fault is a major geological structure across the Brahmaputra where parts of the courses of the rivers- the Brahmaputra, Dhansiri (S), Bargang and many others are aligned along this structure (Figure 6b). The influence of this structure on the courses of these rivers has been studied in detail using topographic maps, satellite data and field evidences. The following main points: a) an unusually linear course of the lower part of the Dhansiri (S) River from Golaghat up to Dhansirimukh, b) the abandonment of the westerly course of the earlier Dhansiri (S) River (flowing through Kaziranga) towards the present NW direction by avulsion, c) knick bends in the MBT-MCT and Naga Thrust of Belt of Schuppen, (d) a linear $15 \mathrm{~m}$ high topographic scarp on the left bank of the Dhansiri (S) at Numaligarh and e) an anomalous SE-NW trending course of the Brahmaputra from Dhansirimukh up to Hartamuli, along with the parts of the rivers Buroi and Bargang on 

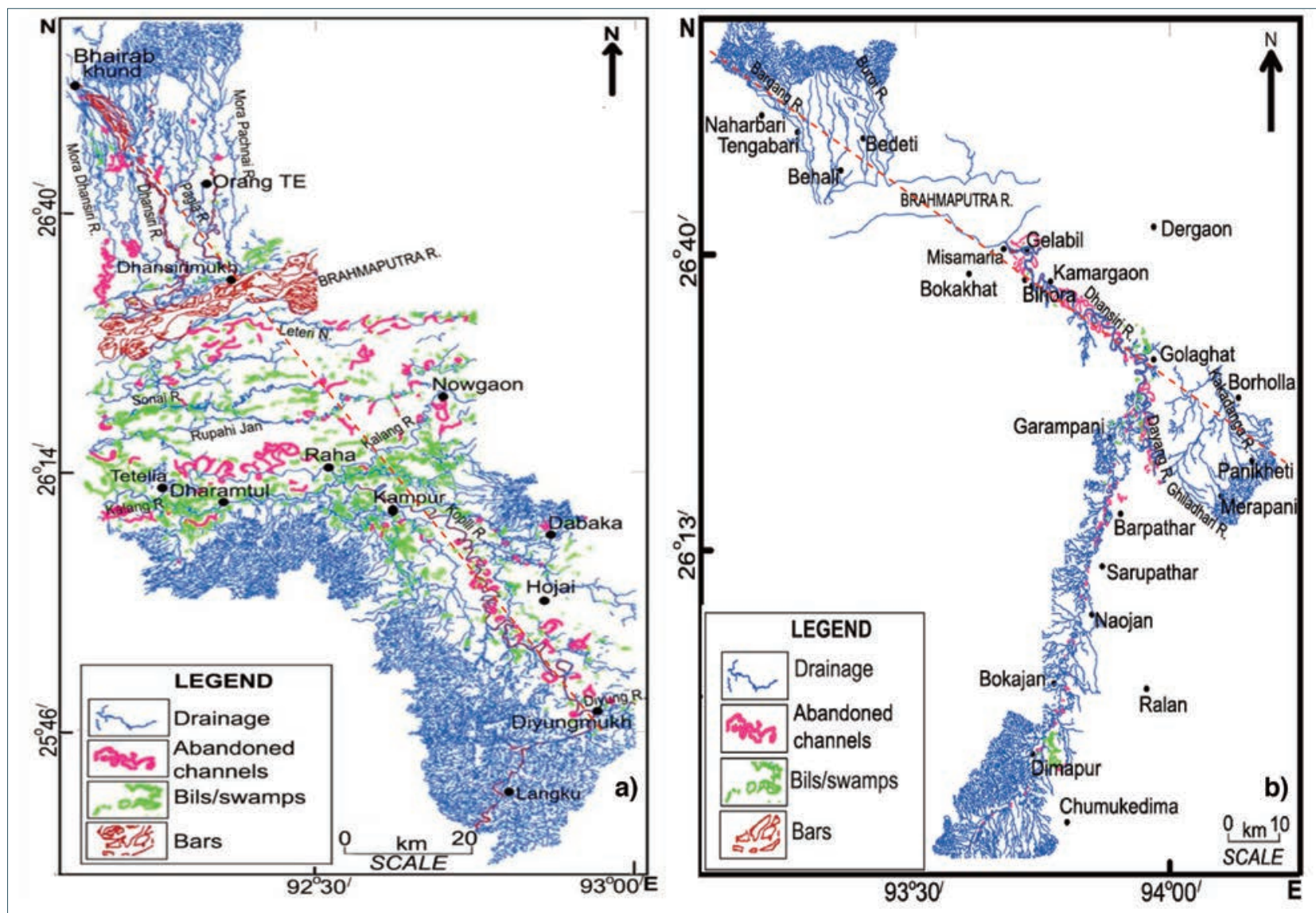

FIGURE 6. Drainage maps showing the a) anomalous linear courses of Kopili-Dhansiri (N) Rivers along the alignment of the Kopili Fault, abandoned channels and the bils/swamps and $\mathbf{b}$ ) anomalous linear courses of the Dhansiri (S)-Bargang Rivers along the alignment of the Bomdila Fault, abandoned channels and the bils/swamps. The Kopili Fault and Bomdila Fault are indicated on the drainage pattern as red dashed lines.

the north in the same trend infer the influence of a fault-type structure. Since all these linear segments of the rivers align over the NW-SE trending Bomdila Fault, they suggest the influence of the later on the courses of these rivers. Moreover, it is believed that the neotectonic activity along this fault might have created the linear high scarp and abandonment of earlier river courses.

\section{DISCUSSION AND CONCLUSIONS}

The Kopili and Bomdila Faults are two major morphotectonic features of Northeast India influencing the neotectonic activities of the region. Both these faults are seismically active which is evidenced from occurrence of large to moderate magnitude seismic events in recent past. Interrelationship between these faults with seismotectonics, gravity, magnetic and topographic profiles is well observed in this region. The epicentral map shows that the Kopili Fault remains highly active towards the northern and the eastern parts while the
Bomdila Fault is active towards the northern and western parts. Both these faults are characterized by strikeslip kinematics with Kopili Fault dipping towards NE direction with an average dip angle of about $75^{\circ}$ and Bomdila Fault dipping towards NNE direction with an average dip angle of $\sim 50-55^{\circ}$. Intense seismic activity occurs to a depth of $45 \pm 2 \mathrm{~km}$ in the Kopili Fault zone while in the Bomdila Fault zone it is $50 \pm 2 \mathrm{~km}$ where large concentrations of earthquakes are observed. However in Kopili Fault, the activity continues with sharp increase in depth from north of Brahmaputra towards north up to MCT and in Bomdila Fault increase in activity is observed up to the north. Although MCT is dormant [Ni and Barazangi, 1984], intense activity is observed at the region where Kopili Fault meets the MBT and MCT [Nandy, 2001, Kayal et al., 2010, 2012]. This is evidenced by the August 19, 2009 Earthquake (Mw 5.1) in the Assam Valley that occurred in the center of the Kopili Fault zone and the September 21, 2009 strong Bhutan Himalaya Earthquake (Mw 6.3) that occurred at the northern end of the Kopili Fault where it hits the MCT [Kayal et al., 2012]. The Kopili fault planes 
show varying orientation dominantly along NNW and NNE. The P-axes indicates a NNE orientation while the T-axes are mostly oriented along NW-SE direction. The Bomdila Fault shows dominant NW-SE trending P-axes while T-axes are mostly oriented along NNW direction. It is observed that the entire Kopili and Bomdila Fault zones are dominated by mostly strike-slip faulting and is believed to extend transversely below the Himalayas to the north and the Belt of Schuppen to the south. The orientation of inferred Bomdila fault plane, typically average NNW, suggests transverse tectonics which is in agreement with regional tectonics down to the depth of bottom of seismogenic zone. The fault planes of both the Kopili and the Bomdila are characteristics of each associated focus at that particular depth. Remarkably at shallower depth near Kopili Fault, the P-axes orientations of few earthquakes are found to be North-South. These variations of axes at depths may be due to transverse tectonics with the availability of geological fractures imaged as LVZs which are possibly zones of denser rocks (Archaen gneiss) under compressional stress in the region.

The gravity and magnetic values over the entire Kopili and Bomdila Fault region varies between -110 and +60 mgals and -80 nT to +90 nT respectively. The curvatures and closures of the gravity and the magnetic contours along the fault lines indicate some hidden structures involving basement and indicate the influence of the faults down to the basement. The sparse distribution of average normal gravity estimates in the central part of the Kopili Fault is due to the thick deposit of alluvium. Here basement is assumed to be a north dipping basin with thickest sediments. The gravity profiles across fault indicate low value along the Kopili Fault. Increase of gravity value to the south of this fault indicates less overburden of sediment thickness. On the other hand the low gravity value over the Bomdila Fault area indicates presence of thick alluvial deposits which progressively become thicker SE of the fault. The gravity profiles from MCT up to north of Naharbari indicate higher gravity value along the Bomdila Fault than in the Kopili Fault indicating lesser sediment thickness in this area. From Naharbari towards Golaghat and beyond (along Bomdila fault), the value of gravity decreases indicating presence of thick alluvial deposits around Golaghat.

The magnetic anomaly map shows high magnetic value near Raha (along Kopili Fault) and Bokakhat (along Bomdila fault), indicating denser as well as highly susceptible shallow basement including presence of ultrabasic rocks. The broad magnetic closures at the southern end near Diyungmukh (along Kopili Fault) indicate change in rock composition within the basement. The magnetic profiles show that from MCT up to Raha the basement is at shallower depth while from Raha up to the southeastern part of the fault the basement is deeper. The Bomdila Fault indicates large crustal heterogeneities. Profile lines show that the fault from MCT to MBT has lower magnetic values indicating deep basement. From MBT towards the Belt of Schuppen, positive magnetic value is observed all along the Bomdila Fault indicating presence of highly magnetic susceptibility materials and basement at shallower depth. Basement being at shallower depth, lower magnetic values indicate presence of thick alluvial deposits.

The neotectonic activities in and around Kopili and Bomdila fault are suggested by anomalous linear courses of some major rivers, river abandonment by avulsion, development of large number of low lands in later period, topographic scarps and development of kinks on existing courses and network of river system which subsequently gave rise to some drainage anomalies.

Thus, the study clearly indicates that both the Kopili and the Bomdila Faults are tectonically active and their trend is clearly discernible from the gravity and magnetic maps. The neotectonic activity is responsible for the existing regional landform and drainage trends in these areas. The indepth study of these faults through multidisciplinary approach helps us in understanding the transverse tectonic behavior of these structures. Moreover, these studies might lead to an understanding of the probable occurrence of any seismic event in the vicinity of these structures in near future and also contribute to the seismic hazard assessment of the region.

Acknowledgements. We thank Dr. D. Ramaiah, Director, CSIRNorth East Institute of Science and Technology (NEIST), Jorhat for his kind permission to publish the work. We also thank Prof. Harsh K. Gupta, Chairman-Research Council, CSIR-NEIST for his constant encouragement. Ministry of Earth Sciences (MoES), New Delhi is highly acknowledged for sponsorship of this study vide sanction no. MoES/P.O. (Seismo)/1(220)/2014. The authors would like to thank Prof. Fabio Villani, Istituto Nazionale di Geofisica e Vulcanologia, Italy and anonymous reviewer for their valuable comments and suggestions which has improved the manuscript.

\section{REFERENCES}

Angelier, J. and S. Baruah (2009). Seismotectonics of northeast India: a stress analysis if focal mechanism solutions of earthquakes and its kinematic implications, Geophysical Journal International, 10.111/j- 
1365-246x.2009.04107x.

BMTPC (2003). Vulnerability atlas 2nd Edn; peer group MOH \&t UPA; Seismic zones of India IS: 1983-2002, $\mathrm{BIS}, \mathrm{GOl}$, Seismotectonic atlas of India \&t its environs., GSI, GO1.

Baruah, S., R. Duarah, and D.K. Yadav (1997). Pattern of Seismicity in Shillong Mikir Plateau and the orientation of compressional axis, Journal of Geological Society of India, 49, 533-538.

Baruah S. and D. Hazarika (2008). A GIS based tectonic map of Northeastern India, Current Sciences, 95, 176-177.

Bhattacharya, P.M., R.K. Majumdar and J.R. Kayal (2002). Fractal dimension and b-value mapping in northeast India, Current Science, 82 (12), 1486-1491.

Bhattacharya, P.M., S. Mukhopadhyay, R.K. Majumdar, and J.R. Kayal (2008). 3-D seismic structure of the Northeast India region and its implications for local and regional tectonics, Journal of Asian Earth Sciences, 33, 25-41.

Bhattacharya, P.M., J.R. Kayal, S. Baruah and S.S. Arefiev (2010). Earthquake source zones in northeast India: seismic tomography, fractal dimension and b-value mapping, Pure and Applied Geophysics, D01: 10.1007/s00024-010-0084-2.

Chen, W.P. and P. Molnar (1990). Source parameters of earthquakes and intraplate deformation beneath the Shillong Plateau and northern Indo-Burma ranges, J.Geophys. Res., 95 12, 527-12, 552.

Dasgupta, A.B. (1977). Geology of Assam Arakan region: Mining and Metallurgy Society of India Quarterly Journal, 49, 1-54.

Dasgupta, S., M. Mukhopadhyay and D.R. Nandy (1987). Active transverse features in the central portion of the Himalaya, Tectonophysics, 136, 255-264.

De, Reena and J.R. Kayal (2004). Seismic activity at the MCT in Sikkim Himalaya, Tectonophysics, 386, 243248.

Ghosh, G.K., S.K. Basha, M.Salim and V.K. Kulshreshth (2010). Integrated interpretation of seismic, gravity, magnetic and magneto-telluric data in geologically complex thrust belt areas of Manabum, Arunachal Pradesh, J. Ind. Geophys. Union, 14(1), 1-14.

Kayal, J.R. (1987). Microseismicity and source mechanism study: Shillong plateau northeast India, Bulletin of the Seismological Society of America, 77, 184-194.

Kayal, J.R. (1996). Earthquake source process in northeast India: a review, Journal of Himalayan Geology, 17, 53-69.

Kayal, J.R. (2001). Microearthquake activity in some parts of the Himalaya and the tectonic model, Tectonophysics, 339, 331-351.
Kayal, J.R., S.S. Arefiev, S. Baruah, D. Hazarika, N. Gogoi, A. Kumar, S.N. Chowdhury and S. Kalita (2006). Shillong plateau earthquake in northeast India region: complex tectonic model, Current Science, 91 (1), 109-114.

Kayal, J.R. (2008). Microearthquake Seismology and Seismotectonics of South Asia, (Heidelberg, Germany), Springer, Germany, 503.

Kayal, J.R., S.S. Arefiev, S. Baruah, R. Tatevossian, N. Gogoi, M. Sanoujam, J.L. Gautam, D. Hazarika and D. Borah (2010). The 2009 Bhutan and Assam felt earthquakes (Mw 6.3 and 5.1) at the Kopili fault in the northeast Himalaya region, Geomatics Natural Hazards and Risk, 1(3), 273-281.

Kayal, J.R., S.S. Arefiev, S. Baruah, D. Hazarika, N. Gogoi, J.L. Gautam, S. Baruah, C. Dorbath, and R. Tatevossian (2012). Large and great earthquakes in the Shillong plateau-Assam valley area of Northeast India Region: Pop-up and transverse tectonics, Tectonophysics, 532-535, 186-192.

Khattri, K.N., M. Wyss, V.K. Gaur, S.K. Saha and V.K. Bansal (1983). Local seismic activity in the region of the Assam gap, northeast India, Bulletin of seismological Society of America, 73 (2), 459-469.

Kumar, D., D. V. Reddy and A. K. Pandey (2016). Paleoseismic investigations in the Kopili Fault Zone of North East India: Evidences from liquefaction chronology. Tectonophysics, 674, 65-75.

Lienert, B.R., B.E. Berg and L.N. Frazer (1986). Hypocenter: An earthquake location method using centered, scaled and adaptively damped least squares, Bull. Seism. Soc. Am., 76, 771-783.

Louvari, E.K. and A.A. Kiratzi (1997). Rake: A windows program to plot earthquake focal mechanisms and the orientation of principal stresses, Computer and Geosciences, 23, 851-857.

McNutt, M. (1980). Implications of regional gravity for state stress in the earth's crust and upper mantle, Journal of Geophysical Research, 85: B11, 63776396.

Murthy, M. V. N., S.C. Talukdar and A.C. Bhattacharya (1969). Bull. Oil Nat. Gas Comm., 6, 57-64.

Nandy, D.R. (1986). Tectonics, seismicity and gravity of Northeastern India and adjoining region: Geol. Surv. India Mem., 119, 13-17.

Nandy, D.R. and S. Dasgupta (1991). Seismotectonic domain of northeastern India and adjacent areas, Physics and Chemistry of the Earth, 18, 371-384.

Nandy, D.R. (2001). Geodynamics of Northeastern India and the Adjoining Region, ACB Publication, Kolkata. 209.

Ni, J.F., and M. Barazangi (1984). Seismotectonics of the 
Himalayan collision zone: geometry of the under thrusting Indian Plate beneath the Himalaya, Journal of Geophysical Research, 89, 1147-1163.

Saha, D., C.S. Bahuguna, J.N. Prabhakarudu and C.L. Baloni (2008). Significance of Gravity and Magnetic data over Thrust-Fold area - A Case Study in the Cachar area of Surma sub-basin of Assam Arakan Basin, Assam, India, 7th International Conference and Exposition on Petroleum Geophysics, Hyderabad, 145.

Saha., D. (2011). Integrated analysis of Gravity and Magnetic data in the Upper Assam shelf and adjoining Schupen belt area, -A critical review, The 2nd South Asian Geoscience Conference and Exhibition, GEOIndia 2011, Greater Noida, New Delhi, India.

Sharma, R., H.C. Gouda, R.K. Singh and B.V. Nagaraju (2012). Structural study of Meghalaya Plateau through Aeromagnetic data, Journal Geological Society of India, 79, 11-29.

Tiwari, V.M., M.B.S. Vyghreswara Rao, D.C. Mishra and B. Singh, (2006). Crustal structure across Sikkim, NE Himalaya from new gravity and magnetic data, Earth and Planetary Science Letters, 247, 61-69.

Vaish, J. and S.K. Pal (2015). Geological mapping of Jharia Coalfield, India using GRACE EGM2008 gravity data: a vertical derivative approach, Geocarto lnternational, 30 (4), 388-401.

Verma, R.K. and R.P. Gupta (1973). Relationship of gravity anomalies and tectonics in Assam, India, Tectonophysics, 18 (1), 19-31.

Verma, R.K., M. Mukhopadhyay and M.S. Ahluwalia (1976). Seismicity, gravity, and tectonics of northeast India and northern Burma, Bulletin of the Seismological Society of America, 66, 1683-1694.

Verma, R.K. and M. Mukhopadhyay (1976). Tectonic significance of anomaly- elevation relationship in Northeastern India, Tectonophysics, 34, 117-133.

Verma, R.K. and M. Mukhopadhyay (1977). An analysis of gravity field in Northeastern India, Tectonophysics, 42, 283-317.

*CORRESPONDING AUTHOR: Saurabh BARUAH Geosciences and Techonology Division, CSIR-North East Institute of Science and Techonology, Assam, India

email: saurabhb_23@yahoo.com 